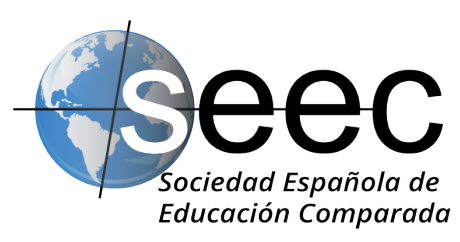

\title{
The Reformation as a Religious, Political, and Educational Project
}

La reforma como proyecto religioso, político y educativo

Thyge Winther-Jensen*

DOI: $10.5944 /$ reec.33.2019.22329

Recibido: 12 de julio de 2018 Aceptado: 7 de enero de 2019

\footnotetext{
* Thyge Winther-Jensen: is Emeritus Professor of Comparative Education at the Danish University of Education, Copenhagen. Previous to that he was a senior lecturer at the University of Copenhagen, Institute of Education. His fields of study are primarily comparative education, history of educational ideas, teachinglearning theory and adult education. From 1996 to 2000 he was President of Comparative Education Society in Europe (CESE). Datos de contacto: E-mail: twj@dpu.dk
} 


\begin{abstract}
This year, five hundred years ago, Martin Luther according to the legend nailed his 95 Theses on the church door in Wittenberg. The Theses, originally written in Latin, were translated into German. Thanks to the invention of the art of printing, "My Theses were truly through all of Germany" Luther later suggested. In a few years they triggered a religious and political transformation in the northern part of Europe, including Scandinavia. This transformation was later termed the Reformation. Today Christian churches rooted in the Reformation are spread all over the world.
\end{abstract}

Key Words: Reformation; Religious Project; Political Project; Educational Project

\title{
Resumen
}

Este año, hace quinientos años, Martín Lutero, según la leyenda, clavó sus 95 tesis en la puerta de la iglesia en Wittenberg. Las tesis, originalmente escritas en latín, fueron traducidas al alemán. Gracias a la invención del arte de la impresión, «Mis tesis fueron verdaderamente a través de toda Alemania», Lutero sugirió más tarde. En pocos años desencadenaron una transformación religiosa y política en la parte norte de Europa, incluida Escandinavia. Esta transformación fue más tarde llamada la Reforma. Hoy en día las iglesias cristianas enraizadas en la Reforma se extienden por todo el mundo.

Palabras clave: Reforma; Proyecto religioso; Proyecto político; Proyecto educativo 


\section{Introduction}

This year, five hundred years ago, Martin Luther according to the legend nailed his 95 Theses on the church door in Wittenberg. The Theses, originally written in Latin, were translated into German. Thanks to the invention of the art of printing, "My Theses were truly through all of Germany" Luther later suggested. In a few years they triggered a religious and political transformation in the northern part of Europe, including Scandinavia. This transformation was later termed the Reformation. Today Christian churches rooted in the Reformation are spread all over the world.

\section{Some first beginnings}

In the wake of the Renaissance, which is primarily described as a secular and humanistic movement, efforts aiming at religious reforms of the Church and Christianity also appeared. However, such reform efforts were not new. The English theologian and dissident within the Roman Catholic Church, John Wycliffe (c. 1325-84), had advocated translation of the Bible into the vernacular. In 1382 he completed a translation directly from the Latin version of the Bible, Vulgata, known as the Wycliffe Bible. In Bohemia he was followed by John Hus (1365-1415) who suffered the fate Wycliffe had avoided: Hus was burned at the stake as a heretic. From the Hus movement - but two centuries later - the famous Czech educationist Jan Amos Comenius (1592-70) embraced a democratic and universal educational ideal: to teach everyone everything thoroughly (omnes, omnia, omnino) with the overall aim preparing for life after death. He belonged to a small Protestant sect, called "The Bohemian or Moravian Brothers", which had developed as an offshoot of Johan Hus' opposition to the Church of Rome.

Of course protests had occurred before Luther too. For example, in Italy the Dominican friar Girolamo Savanorola (born1452) was shaken by the scandalous conduct of Pope Borgia. He was arrested, tortured, hanged and then burned at the stake in Florence in 1498. Some of his writings impressed Luther but, unlike Wycliffe and Hus and Luther, Savonarola never objected to the theology of the Roman Church. His protest was purely moral.

Such heretical movements were for a time successfully fought against by the Roman Catholic Church but it became more and more difficult for the Roman Church to preserve its authority and integrity. Its inner secularization during the Renaissance weakened the respect for it by sincere Christians and opened the way for further critique and accusations from the outside of not living up to its own religious and moral norms.

Critique from the inside inspired by Renaissance humanism was well-known as well. The insider critics, however, were not aiming at a rupture with the Catholic Church, they only wanted to reform it. Such critics included Erasmus of Rotterdam and the Danish Carmelite friar Poul Helgesen from Elsinore who was accused of preparing the way for the Danish Reformation although he was a prominent and tough critic of Lutheranism. The whole body of his work was published recently, among them the so-called Skibykrønike (Skiby Chronicle). The Chronicle was a "historical work in which he describes events from Christian I (1448-81) onwards. In hard and merciless terms he portrays the spokesmen of the Lutheran Reformation - some of whom were his former students; but just as hard and merciless are his portrayals of the leading figures of the Catholic Church because of their incompetence in church matters and in their lust for power" (Laustsen, 2011, 24). The Chronicle was not found until the seventeenth century. It had been walled-up behind 
the altar in the church of Skiby on Zealand. It stops in the middle of a sentence about the year 1535 and maybe it was hidden then because of its content - undoubtedly dangerous - in the middle of the civil war before the Danish Reformation in 1536.

Compared with the Renaissance, the chief point about the origins of the Reformation is that they were purely religious. Later developments, however, added a strong political side which meant that the universal Catholic Church in parts of Europe was replaced by national churches. For these parts of Europe the Reformation also meant radical changes in education and for mentality in general. But how profound these changes were is still being discussed. For example, how strongly did Protestant education influence protestant mentality? In Die protestantische Ethik und der Geist des Kapitalismus (The Protestant Ethic and the Spirit of Capitalism, 1904/05) the sociologist Max Weber put forward the thesis that the Protestant work ethic was an important factor behind the emergence of capitalism. If true, the idea seems to apply better to Calvinism than Lutheranism. A certain connection, however, might be seen in the circumstance that Protestantism compared with Catholicism represents a religious individualism while capitalism represents an economic individualism.

An exploration of the relation between Protestantism and society in general might begin at Wittenberg in Germany where the Reformation started.

\section{Wittenberg}

Today Wittenberg is part of Saxony-Anhalt but in the sixteenth century it was part of the Saxony Electorate in the Holy Roman Empire and a small city with about two thousand inhabitants. It happened however to contain not only the main figure of the Reformation, the famous member of the Augustine monastic order, Martin Luther, but also a constellation of persons and institutions that made possible the success of the religious doctrines behind the Reformation.

One of these persons was the local Elector Friedrich III (Friedrich "the Wise") and Wittenberg was one of his residences - that is, it was politically under his control. Although Friedrich remained a Catholic all his life he nevertheless turned out to be an important supporter of Luther and the Reformation. When the Pope in 1518 demanded Luther be handed over for prosecution because of the 95 theses Friedrich refused and argued instead for a public debate to settle the religious questions. In the middle of these conflicts the Holy Roman Emperor Maximilian I - a German - died which was fortunate for Luther. As one of the seven Electors, Friedrich was a central person in the election of the new Emperor. The Pope and the future Emperor Charles V needed his support. This meant a pause in the prosecution. When the case was taken up again in 1520 Friedrich claimed - probably to gain time - the new faith could no longer be stopped. It had already been adopted by too many both inside and outside the Church. And when Luther in 1521 refused to withdraw the Theses at the Diet of Worms it was again Friedrich who hid him in Wartburg castle until the danger was over. Luther spent his time in Wartburg translating the New Testament from Greek to German.

Martin Luther himself was born 1483 in Eisleben where he also died 63 years later, in a house not far from the one in which he was born. He joined the Augustine monastic order, was ordained as a priest in Erfurt Cathedral in 1507, defended his doctoral thesis at the new university in Wittenberg and was shortly after appointed Lectura in Biblia, i.e. teacher in biblical studies at the university. He held this post to his death. 
According to Luther, man was not justified in the eyes of God by prescribed merits or by good deeds but by faith in God's word alone (sola fide) as preached by the Gospel alone (sola scriptura), and testified as salvation by God's grace alone (sola gratia).

The three principles form the essence of Lutheranism. Sola scriptura became the rallying cry of the Protestant Reformation. First of all it called for translations of the Bible into the vernacular, secondly for improved reading skills among all citizens. The Reformation can be seen as the start of a gigantic educational project, a recasting of whole populations, that came to last several hundred years although at the start it was far from promising.

Removal of monasteries and monastic orders threatened to destroy the schools, mostly attached to the monasteries. References to the importance of education are therefore to be found throughout Luther's production. Most urgently in An die Ratsherren aller Städte deutschen Landes, dass sie christliche Schulen aufrichten und halten sollen (To councilmen of all cities in Germany that they establish and maintain Christian schools, 1524) but later also in Eine Predigt, dass man die Kinder zur Schule halten (A Sermon on keeping Children in School, 1530) as the effect of the first appeal did not come up to his expectations. Together, the two appeals form Luther's classic statements on the subject of education. In an intense and often heated language he tried to make it clear for all authorities that education is a matter of vital importance for "if the Scriptures and learning disappear, what will remain in the German lands but a disorderly and wild crowd of Tartars and Turks, indeed, a pigsty and mob of wild beasts" (A Sermon...p.3)

As a reformer, Luther was a hardworking writer and an inspiring lecturer. Many were attracted by his teachings, among them a young man who was appointed Professor of Greek in Wittenberg at the age of twenty one. His name was Philipp Melanchton (14971560). Even more than Luther he is an illustration of that the Reformation was not only a religious but also an educational project. In his career he combined the reconstruction of learning with the reform of the church and deserved the title Praeceptor Germaniae (Teacher of Germany) because of his influence on the development of the German education system, especially the School Ordinance for Saxony. Ordinances were legislative documents of regulation for the organization and operation of schools in German Protestant realms. He was also the author of many textbooks, grammars, and handbooks of education mostly in relation to reform of the Latin schools.

In the educational programme, which he already announced at his inaugural lecture, On improving the Studies of the Youth (1518), he combined development of humanistic inspired skills like reasoning, eloquence and fine writing with study of the sources, especially the Scripture. In the demand for a return to Scripture as the true source of study he was in full agreement with Luther.

A lifelong friendship developed between Melanchton and Luther and Melanchton became a strong supporter of Luther's new doctrines though there were differences:

"The alliance between the two minds of Luther and Melanchton, who between them moulded the Lutheran reform, is a fascinating story, for they were unequal yoke-fellows. The vehemence of the one versus the pacific nature of the other; the pastoral soul versus the scholar and intellectual; the apostle of the poor and simple versus the apostle of higher education; the pilgrim marching to his God through clouds of demons and temptations versus the moderate student of truth; rough peasant manners versus gentle courtesy; courage versus timidity; stand for truth though the Church fall versus the reasonable thinker ready to meet opponents half-way if he could; the enemy of Erasmus versus his friend - both of them found the alliance embarrassing and painful” (Chadwick, 1990, p. 66) 
Johannes Bugenhagen (1485-1558) was also important. As vicar at the city church and professor of theology at the University of Wittenberg he became Luther's confessor and spiritual advisor. In their younger days he and the later Danish King Christian III had met each other. A lifelong friendship had developed between them which might be one of the reasons why he became an important player in creating the intellectual foundation of the Danish-Norwegian Reformation.

Many students from Denmark and Scandinavia in general went to Wittenberg whose fame gradually spread outside of Germany. Among the Danish students was no less a person than Hans Tausen. After studies in Copenhagen, Rostock and Leuven he finished his studies abroad in Wittenberg and later he became a main figure in the process that finally resulted in the introduction of the Reformation in Denmark. He is also spoken of as "the Danish Luther".

Without the help of painters and printers the new teachings would probably never have got off the ground. Not far from the university in Wittenberg was the painter Lucas Cranach's big workshop (Today it is a museum). From this workshop a stream of woodcuts were sent out which showed the difference between Christ and Antichrist (i.e. the Pope). Like Melanchton, Cranach became a friend of Luther and worked closely together with him. You may now and then see him referred to as the "the reporter of the Reformation".

Of course, the Roman Catholic Church also made use of the new printing techniques, e.g. printing large numbers of the controversial Letters of Indulgence that were sold to save souls from Purgatory - and to finance, among other things, the building of St. Peter's in Rome.

There is no doubt that Wittenberg - with its specific constellation of political interests, intellectual power and new media that both protected and supported the young, radical movement - functioned as an effective machine for the Reformation and lasted long enough for the new movement to gain a foothold in big areas of northern and western Europe (Arentoft, 2016). But had it not been for Friedrich III, (insert comma) Luther would probably have suffered the same fate as the previous reformers mentioned above. He only just escaped the stake. When finally serious steps were taken to stop him it was too late. The Lutheran ghost had already slipped out of the bottle and his extensive writings together with documents like The Augsburg Confession (1530) ${ }^{1}$, and The Religious Peace of Augsburg (1555) established the new faith. But it all started with the 95 Theses in 1517.

\section{The 95 Theses}

Although the Theses today are looked upon as a historical document and in a way seem only to attack a specific church practice of that time (the selling of Letters of Indulgence) they nevertheless inaugurated a radical break with some of the ideas put forward by the "old" church, i.e. the Roman Catholic Church.

Studies of the Bible, Paulus, and Augustine had convinced Luther, as he declared in Thesis 62, that the true treasure of the Church is the Holy Gospel and God's grace. Also, God's grace is unconditional and given by God only: "Any truly repentant Christian has a right to full remission of penalty and guilt, even without indulgence letters" (Thesis 36). Selling Letters of Indulgence is the Church's own invention and will free no one from the

1 http://www.stpls.com/uploads/4/4/8/o/44802893/augsburg-confession.pdf 
torments of Purgatory: "Thus, those indulgence preachers are in error who say that a man is absolved from every penalty and saved by papal Indulgences" (Thesis 21).

The Theses also contained a social critique as they claim that the money spent on Letters of Indulgence would find better use if it were given to the poor: "Christians are to be taught that he who gives to the poor or lends to the needy does a better deed than he who buys indulgences" (Thesis 43).

Readers today might be surprised that the Theses, relatively moderate as they are, gave rise to so much resistance from the authorities. Especially two of the theses were seen to be contrary to the doctrines of the Church. In Thesis 58 he denied that the merits of Christ are the property of the Church and in Thesis 7 he claimed that the sacraments can only be received rightly through faith and belief in God: "God remits guilt to no one unless at the same time he humbles him in all things and makes him submissive to the vicar, the priest".

Although Luther probably only had a reform of the church on his mind when he formulated the Theses they nevertheless provoked the clerical and secular authorities. He was asked to withdraw them but refused to do so at a Diet in Augsburg September 1518. Two years later in June 1520, he was declared a heretic, excommunicated, and banned by the Pope (Tomlin, 2004, p. 83).

The next step was to have him declared an outlaw by the Emperor Charles V. He was granted safe passage to a Diet in Worms and resolved to go although it was a risky journey to undertake - Hus was granted safe passage to Constance but was burnt. But Luther decided to go. On April 18, 1520 he was asked, in the presence of the Emperor, whether he would recant the Theses with other of his writings like Resolutions Concerning the 95 Theses, On the Papacy at Rome, Address to the Christian Nobility, The Babylonian Captivity of the Church, and On the Freedom of a Christian. As is well known, he refused to recant with the following famous statement: "Unless I am proved wrong by Scriptures or by evident reason, then I am a prisoner in conscience to the Word of God. I cannot retract and I will not retract. To go against the conscience is neither safe nor right. God help me. Amen" (Chadwick, 56). Shortly after, he was declared an outlaw by the Edict of Worms issued by Charles V.

In a last attempt to reconcile the followers of Luther with the Roman Catholic Church Luther was ordered to arrive at a Diet in Augsburg in 1530. As an outlaw he was not able to go there himself. Melanchton went instead. In consultation with Luther he prepared beforehand a founding Evangelical-Lutheran confession, later called the Augsburg Confession, which he presented to the members of the Diet.

\section{The Augsburg Confession 1530}

The confession, originally a description of belief and church system in the principalities and cities that had joined Lutheranism, consists of 28 articles. The first 21 "Articles of Faith" deal with the ways in which the preaching takes place in "our churches", i.e. the Lutheran communities.

The last seven articles deals with "Eliminated misuses" such as the celibacy of priests, monastic vows, the Mass etc.

The Confession was offered in a conciliatory tone and concludes "that there is nothing that differs from the Catholic Church or from the Church of Rome as known from its early writers". The Lutheran criticism, however, that the Roman Church since its 
early days has left the true teachings of the Bible is obvious to the reader and such criticisms were not surprisingly rejected by Charles V and the Catholic majority at the Diet in Augsburg. But had the members of the Diet listened more carefully to what Melanchton had to say and been ready to seize the opportunity, a split in the church might have been avoided.

The Confession later came to be the basis of the Reformation in the North. In Denmark it has functioned as the official belief of the church since the Reformation in 1536.

\section{The Peace of Augsburg 1555}

In 1546, the year of Luther's death, Charles V started a war against the Lutheran princes and a year later he defeated their armies. In consequence the princes were forced to sign a peace declaration, the so-called Augsburg-Interim, in which the Emperor demanded Catholicism restored in all Lutheran areas. Priests were still allowed to marry, though, and the Lord's Supper could still be given as bread and blood to the laity. But time had run out for the Charles V. The fortunes of war shifted. He now lost on the battlefield to the German princes and the Pope did not support his idea of a compromise between Catholicism and Lutheranism. Disillusioned, he left his younger brother Ferdinand to chair the peace negotiations in Augsburg in 1555. It was decided that Catholicism was still the religion of the Holy Roman Empire but those who acknowledged the Augsburg Confession were also tolerated. According to the principle of Cujus regio, ejus religio (Whose realm, his religion) the faith of the ruler dictated the religion of his subjects. Those subjects who could not subscribe to their ruler's religion were permitted to leave the territory with their possessions. The principle reduced the risk of civil wars but the Declaration also gave legitimacy only to two forms of religion within the Empire: Roman Catholicism and Lutheranism, leaving out other Reformed versions of Christianity such as Calvinism. The reformed versions were in fact legalized only with the Westphalian Peace in 1648 which ended the Thirty Years' War.

In other words, already from the beginning differences in religious understanding were embedded in the Reformation. It might therefore be more to the point to talk of Reformation in the plural instead of in the singular.

\section{The Reformation in Switzerland and France}

During his years of study the Frenchman Calvin got into contact with Luther inspired circles in Paris and Orleans and after intense readings of the Bible he converted to Lutheranism. In 1541 he was called to Geneva as a priest and created here an independent reformatory church, an act which had effects far outside Europe. Although influenced by Luther he interpreted the Gospel differently on certain points. Faith and forgiveness were not so much a question of absolute trust in a merciful God but in God as an elevated majesty with the Bible as the great law book for church and life of Christians. What he imagined was probably some kind of theocracy, i.e. a system of government in which the laws of the state are believed to be the laws of God.

But the crucial characteristic of Calvinism undoubtedly was the Doctrine of Predestination claiming that some are "preordained to everlasting life", others "foreordained to everlasting death". As an individual you do not know which of the two groups you are preordained to. From a superficial consideration this might be taken as a sign to 
sit back. It is already decided to which of the two groups you belong. In practice, however, it had the opposite effect. A pious and active life was seen as the most certain sign that you belonged to the chosen.

From that perspective also education became a matter of great importance. Calvin's principal work Institutio religionis christianae (Instruction in Christian religion, 1535) carries a half educational title. In his school plan, all forces were mobilized to uphold his view on Christianity. Prayer, hymn singing, Bible reading, and church attendance played an important role and were maintained as duties no one should avoid. At his Academy and gymnasium in Geneva discipline was strict and school life was marked by gravity and temperance in relation to worldly pleasures.

In Calvin's schools those men were educated that brought Calvin's doctrines to France, to Puritans in England, and to Presbyterians in Scotland. At the same time they initiated schools in their countries. It followed naturally that these schools were maintained by the church not by the state.

In Germany Calvin's followers were given the name "the Reformed" and they were, as such, excluded from the Peace of Augsburg. In France they became subject to severe persecutions but at a synod (meeting) in Paris in 1559 the French Protestants succeeded in agreeing on a Calvinistic confession and an order of the church modelled after the church in Geneva. Since then, this so-called Presbyterian Church Order has been a conspicuous characteristic of the reformed churches. The independent congregations are governed by a consistory, i.e. a court of presbyters (elders) to deal with church business and with a General Synod as the highest authority.

From France, Calvinism spread to The Netherlands where it was fought against by the Spanish King, Philip II. The result of the resistance against Spanish control was that the fight for national freedom and for Protestantism went hand in hand. In 1581 the Netherlands were declared an independent state with extensive religious freedom but in reality with Calvinism as the official religion.

\section{The Reformation in England and Scotland}

In England the ground was prepared for a Reformation because of the stir caused by John Wycliffe's activities. Later, in the 1520 s there was a growing awareness of Luther's writings and in 1525-26 William Tyndale published a translation of the New Testament, a linguistic masterpiece which became one of the most effective means in the spread of Protestantism in England. The Catholic Church reacted strongly to this new development but it was the King, Henry VIII, and not the Church that came to influence it. Although a Catholic himself - earlier the Pope himself had conferred on him the title 'Defender of the Faith', the acronym of which can still be seen in Latin on coins in the UK - Henry nevertheless saw himself as head of a national Church which in terms of economy, administration and law was independent of Rome. He confiscated Church properties and succeeded in making his new church independent of Rome without breaking the balance between Catholicism and Protestantism. It was not until the Pope denied his divorce from the Queen, Catherine of Aragon, that the balance was broken. In consequence of the denial Henry appointed as Archbishop in Canterbury Thomas Cranmer, who was a leader of the English Reformation and close to German Protestantism. Cranmer helped preparing the annulment of Henry's marriage and in 1534 Henry was declared "the only supreme head on Earth of the Church of England" (First Act of Supremacy). The year 1534 is often taken as a mark of the beginning of the Reformation in England. 
It was the hope now that Henry could be won for the Reformation but he later returned to a sharp anti-Lutheran policy which led to the execution of a great number of Protestants as heretics. Cranmer survived, though, and kept his position as Archbishop in Canterbury during the reigns of Henry and Henry's son Edward VI but after the accession of the Roman Catholic Mary I, daughter of Henry, he was put on trial for treason and heresy and finally executed. Life was dangerous in those days.

In 1558, another daughter of Henry, Elisabeth, ascended the throne. In contrast to her sister she apparently had a more relaxed and pragmatic approach to religion. But like her father she wanted an English national church independent of Rome and with herself as "supreme governor" (Second Act of Supremacy, 1559) (Chadwick, 1990, pp. 129-132). She realized that the only way in which she could reach that goal was to base her power on the reform movement.

During the reign of Elizabeth the final consolidation of the Anglican Church took place. The so-called Common Book of Prayer, the first edition of which was written by Thomas Cranmer (1549), now came out in a new edition showing greater respect for the Catholic tradition in liturgy, i.e. the fixed form of public worship used in church, while the reformatory influenced doctrines of the church were committed to paper in the Thirty-nine articles and incorporated in the Common Book of Prayer. The articles were in fact the result of former versions with roots back to both Lutheran (Augsburg Confession) and especially Calvinist doctrines (Cranmer). Although the Common Book of Prayer did not put an end to religious conflicts between Catholic and Protestant monarchs and citizens it formulated the English reformed doctrine including and at the same time moderating the conflicting views.

No wonder therefore that the Anglican Church has been characterized as a version of the Reformation different from Calvinism as well as Lutheranism. "In quite a different way from the churches on the continent it saved the continuity with the church of the Middle Ages. It applies above all to the organization of the church which is Catholic apart from the fact that the Pope is not recognized. The English church is a typical bishop church in which the authority is due to the ordination inherited in an unbroken line from the Apostles until today. But also the service has saved the continuity... What was wanted was a Catholic Church independent of the Pope and with the reformatory understanding of the Gospel" (Koch, 126).

The Anglican Church developed as a compromise between the Catholics who wanted to restore the "old" church and those who wanted a "pure" church. Indirectly out of this comes the name 'Puritans'. As the state demanded uniformity and that service to be practised in accordance with the Common Book of Prayer the Puritans were faced with a difficult choice. Some ended up accepting the state church and its service. Others were caught in a bitter fight with the result that state policy was tightened up against all forms of separatism.

In consequence of this, emigration started from the beginning of the seventeenth century - first to Switzerland and the Netherlands - later to America where the emigrants created a number of states with Presbyterian-Calvinistic churches or free churches. Emigrating from a nation where they felt their beliefs had been oppressed they wanted the new churches established without state interference. Part of the result was the still existing separation of state and church in the United States.

Back in England, however, the indignation at the coercive measures led to new considerations on the relation between state and church. The so-called Independents 
advocated that the only way out of the conflicts was to leave it to the single congregation to decide on its own matters and to let them to be independent of each other and especially of the state. The Civil War (1642-51) between Parliamentarians and Royalists which ended with Parliamentarian victory also meant that the monopoly of the Anglican Church on Christian worship was broken. Under the leadership of Oliver Cromwell and the Independents a new regime was established in which religious freedom was taken for granted and persecution because of belief was banned.

The dramatic events in England formed the Reformation in England in a specific way and resulted in a service and church organization that differed considerably from the protestant churches on the Continent. In a strange way and in spite of conflicts and civil wars England succeeded in muddling its way through to a Reformation with greater religious freedom but also without breaking fully with older traditions.

The English Reformation affected education in different ways. Like in other reformatory countries, first of all through Bible translations. But also through re-foundation of older schools or conversion of them into free schools. Furthermore, the abolition of former monasteries also meant a foundation of a number of new grammar schools. The new and re-founded schools provided the greater part of English education till the eighteenth century.

The development in Scotland also differed from the one in England. During a stay in Geneva, John Knox (1505-72), originally a Catholic priest, had become committed to the Calvinistic spirit. On his return to Scotland he was a decisive influence on church matters in strong opposition to the Royal dynasty. "The result was that Reformation was introduced quickly in all Scotland and practised in a strictly Calvinistic form within a Presbyterian Church arrangement so that Scotland in many ways became the Promised Land for English Puritans..." (Koch, 127).

He (Knox), in his Book of Discipline, (had) suggested a church-controlled plan of education for all, for rich and poor, and from primary to university level. "The plan, however, was too expensive to carry out but the spirit of it seems to have had some effect as education has always been of a relatively high standard in Scotland and been appreciated in all social classes”. (Grue- Soerensen, 1956, vol. 1, p. 229-30).

\section{The Reformation in Scandinavia}

After the notorious Massacre of Stockholm in 1520, organized by the Danish king Christian II (1513-23), Sweden left the Kalmar Union between Denmark, Norway and Sweden and appointed Gustav Vasa as King of Sweden. He carried through the Reformation in Sweden and replaced Catholicism by the Evangelical-Lutheran Church in 1527.

In Denmark-Norway (including also at that time the Duchy of Slesvig-Holstein, the provinces Skåne (Scania), Halland and Blekinge in Sweden, and Iceland) the transition to Lutheranism was carried through in 1536 by Christian III and adopted three years later in Norway. At the age of seventeen Christian III (1534-59) had attended Luther's defense at the Diet of Worms (1521). From that day on he had been a convinced and devoted Lutheran. Therefore, in his capacity as the Duke of Slesvig and Holstein he had already introduced a Lutheran church order in his realms before the election as King.

In Iceland the transition proved more difficult. Lutheranism was not implemented by King Christian III until 1552 after the execution of the last Catholic bishop Jòn Arason.

Today the Scandinavian churches, the Church of Sweden, the church of Norway, the 
Church of Denmark, and the churches of Greenland and the Faroe Islands are all rooted in Lutheran church orders established during the Reformation.

It was not obvious that a Lutheran should be elected as King of Denmark-Norway. When the previous king, Frederik I (1523-33), died the most obvious choice would be his oldest son Christian, Duke of Slesvig and Holstein. However, as a convinced and devoted Lutheran he was an unacceptable choice for the majority of the Rigsråd (the Council of the Realm) whose task it was to elect the new king. The Council, consisting of about 25 powerful members from Church and Nobility, could not come to an agreement as most nobility members and all bishop members, preferred a Roman Catholic king on the throne. Instead the election was postponed, all Protestants were declared outlaws, and a trial was started against Hans Tausen. On his return from studies in Wittenberg he had begun preaching the gospel in Viborg in Jutland and was now considered the most prominent Lutheran in Denmark.

What happened next is yet another example of how religious and political matters were intermixed. (Danmarks historie, vol. 6, pp. 11-195). The Hanseatic town south of Denmark, Lübeck, wanted to regain its former position as the most important commercial city in the Baltic area. The Netherlands stood in its way and the Rigsråd was asked for support. But the request was refused, probably because Holstein had already allied itself with the Netherlands and because the members might have been frightened by Lübeck's reputation as a stronghold of Lutheran ideas.

Lübeck reacted by landing an army of German mercenaries on Zealand under the command of Count Christopher of Oldenburg. Members of the nobility in the Rigsråd now realized that a leader was needed to defend their properties and restore peace. It was finally decided - under public pressure and to the despair of the Catholic bishop members - to elect Duke Christian as King Christian III.

What followed was a brutal civil war between two parties - both of Lutheran observation - called Grevens fejde (The Count's Feud - after Count Christopher). In fact it now became more a class than a religious struggle between on the one hand commoners and farmers and on the other hand the King and the nobility. In Jutland citizens and farmers were defeated by Christian and his commander Johann Rantzau. The leaders were executed and the farmers punished economically so harshly that the effects were felt for years. After Jutland, Funen and Zealand were conquered. The citizens of Copenhagen were the last to surrender after a one-year siege. The sufferings were appalling; it was a miserable sight that met Christian III in August 1536, when he rode into an exhausted, beaten and starved city.

The surrender prepared the way for a coup d'état. Within the next 24 hours all Catholic bishops were arrested and imprisoned and the remaining members of the Rigsråd were confronted with an ultimatum either to sanction a total secular regime, i.e. a regime with no bishops taking part in matters of government, or go to prison (Hørby 1990, p. 29) and further, not to oppose the Lutheran doctrines being preached from now on. At a Diet in October the same year the new arrangements were settled. The Catholic bishops should be removed "because of their misdeeds" and replaced by so-called Christian bishops able to promote among people the holy gospel, the words of God, and the holy Christian faith (Laustsen, 1990, 101). The bishops' properties were confiscated "for the support of the Crown and the King" and "for the common good of the kingdom". The king was also given the right from now on to appoint persons to all posts in the church. Monasteries and convents were maintained till the king "with wise and erudite men" had arranged for 
a new church order. Monks and nuns were at liberty to leave or allowed, if wanted, to stay until they died and the monasteries were shut.

Melanchton was invited by the king to come and prepare the new church order but it was Johannes Bugenhagen who was sent. He (and probably Luther as well) approved and added the finishing touches to Kirkeordinansen (The church ordinance)

"Oneyear later (August/September 1537) the final implementation of the Reformation was marked by four events: 1) Johannes Bugenhagen crowned and anointed in a fine "reformatory" celebration the royal couple in Our Lady's Church in Copenhagen. 2) He ordained in the same church the seven new Lutheran bishops. 3) The King signed The Church Ordinance, and 4) the University of Copenhagen was reopened, now as a Lutheran institution" (Laustsen 1990, 103).

Concerns about learning and education in the Danish church during the Reformation were similar to those in the evangelical parts of Germany but these concerns played themselves out under quite different circumstances. "German princes and cities had to cope with the intricacies of imperial law and with the constant threat of political intervention, whereas Christian III had a free hand as soon as he had put an end to the civil war and removed the only obstacle to the Reformation worth mentioning - the episcopacy of the national Catholic church. Already his father Frederick I (1523-1533) had, to all practical purposes been head of the church, although this fact was not stated in an official way that could be compared with the Act of Supremacy of Henry VIII. Many problems that worried German magistrates simply did not exist on Danish or Norwegian soil. The King could combine his sovereignty over the church with a very clear program for its functions" (Grane, 1990, p. 164) and fully, you might add, in accordance with the "cujus regio, ejus religio" principle.

The new program was writ down in a church law, the Ordinance of 1537/39. The law dealt with not only matters of church but also with education and care of the poor and sick. From the beginning, introduction and maintenance of the faith was seen in combination with education. "The royal Danish Reformation was not only an attempt to reshape church government and religious ceremonies, but even to remodel the mind of the Danish people”. (Grane, 1990, p. 164).

Hans Tausen and other Danish theologians who had studied in Wittenberg made the first draft of the law and it was sent by the King to Luther and Bugenhagen for approval. Bugenhagen came to Copenhagen in July 1537 and later the same year a Latin version was signed by the King. A Danish translation made by one of the seven new bishops or "superindendents". Peder Palladius, was approved by Rigsrådet two years later. Bugenhagen spent two years in Copenhagen before he returned to Wittenberg.

The law might well be seen as an example of the extent of the influence that went out from Wittenberg in those days but also as one of the most typical examples of how Lutheran reformers imagined the relation between state (king), church, and education. Probably, Bugenhagen went farther, though, to please the King than Luther imagined. Luther's idea was that church and state were two separated "regiments" or "kingdoms" but in the Ordinance the King was trusted with power and full responsibility towards both "regiments".

Until the Constitution of 1849 the Danish church, Folkekirken, was a state church in which the inhabitants became members by birth, today by baptism. The present Constitution of 1953 still states that "The Evangelical Lutheran Church shall be the Established Church of Denmark, and as such, it shall be supported by the State". Up to 
the 1930 s the vicar was ex officio Chair Person of the School Board but school and church are now fully separated

The state support is no hindrance for religious freedom and diversity, but does not indicate equality of religions either. Folkekirken is backed by about $77 \%$ of the population, in Copenhagen less than $60 \%$. The remaining $25 \%$ consists of a large number of Christian, non-Christian church societies, and non-members. Ca. $5 \%$ of the population are Muslims.

\section{Conclusion}

The described cases seem to justify the above mentioned statement that instead of talking of the Reformation in singular it might be more to the point to talk about Reformation in the plural. The cases also point at the importance of historical background to understand and maybe even to explain why a movement like the Reformation took on different forms and influenced education in different ways as it spread through parts of Europe. In fact, the cases deserve a more systematic comparative analysis by, say, a set of 'unit ideas' like space, time, state, educated identity, transfer, praxis. (Cowen, 2009, p.1285).

On the other hand there are many similarities that point at the Reformation as a unified movement although the understandings behind differ. One such recurrence, total rejection of the Pope as the highest authority of the church, is a very conspicuous one.

The church reformers wanted a break with what they saw as a centralized, authoritarian and corrupt institution and the political leaders - kings, monarchs and princes - had an open eye for the church as the owner of big territories and gigantic fortunes.

Church reformers and secular authorities, therefore, could meet in a common agreement to establish on the one hand national churches set free from the idea of the Pope as an indispensable station between God and individual man and on the other hand a take-over of church properties in order to strengthen the Crown. This is a weighty argument as well for the point of view that the Reformation was just as much a political and economic movement as a religious.

It is a point of view also well in step with Luther's own thoughts. The church should preach the Gospel only and not reach out for economic and political power. The duty of the state on the other hand should be to take care of political and social affairs and to protect the church without interfering in its internal affairs. The state was welcome to seize big parts of the church possessions but they should be used for social purposes. "In this way Luther's theology had profound effects on social life. In many ways the ground was here prepared for a modern understanding of society and it is obvious too that many non-religious factors came to play a role in the spread of the Reformation in Europe" (Laustsen, 2011, p. 21).

The central position ascribed to the Bible is another shared element in reformatory theology. The Catholic Church was accused of for centuries to have made established practice like indulgence, purgatory, sacraments, pilgrimages etc. superior to the Bible.

Of great educational importance were Luther's Small and Large Catechisms. They were published in 1529 and have until recently been basic textbooks for religious instruction in the countries that adopted Lutheranism. Translations of the Bible might be seen as one of the most lasting educational effects of the Reformation because of the importance they had for the development of national languages. The first translation into Danish was Cristian III's bible (1550). 


\section{Today}

Since Luther put up his theses more than 800 million people out of the 2.2 billion Christians in the world belong to a religious community related to the Reformation. And not only have the number of followers increased. The same applies to the number of churches of which several thousands have been identified all over the world. In South Korea alone you can find about eighty different protestant churches. In other words, today the Protestant churches are characterized by great diversity. From one point of view it signals freedom in matters of belief. The Reformation set man free and was a necessary step against a powerful church that had gone astray. From another point of view the conflict between Pope and reformers led to a regrettable split of the church. Although it was the Pope himself who kicked Luther out of the church by excommunicating him, the split was nevertheless unhappy and let to a lot of bloodshed. Now, there is no way back but it is still a question for discussion whether a diversified or a unified church is the best suited to meet the challenges of today. And how, indeed, should a unified Christian church be organized today?

Another question for discussion is the relation between church and state. In the Scandinavian countries the number of members is declining. Globalization and immigration make it difficult for the traditional Lutheran churches. In 2000 the Swedish church was separated from the state and at the beginning of 2017 the Norwegian Evangelical church was declared an independent religious community but still state supported economically and included in the constitution. In Denmark the question is still on the political agenda. In Sweden the separation has resulted in a distinct politicization because the political parties want to be represented in the parochial church councils. Against which many have reacted by resigning their membership.

As always, it is a question of finding the right balance between diversity and unity, between state and church etc. But one thing is for sure: the religious instinct is too strong to be left alone. History, but also the world around us today, still tells us how important it is to have it canalized into civilized and tolerating forms.

Europe has experienced two great educational projects: The Reformation and the Enlightenment. There were two hundred years between them. More than the Enlightenment, the Reformation prepared the ground for democracy through education. More than the Reformation, the Enlightenment prepared the ground for science as a challenge to revelation and religious doctrines. But in combination, the two educational projects formed the present face of Europe.

\section{References}

Arentoft, F. (2016). Reformationsmaskinen i Wittenberg (The Reformation Machine in Wittenberg). Kristeligt Dagblad (Christian Daily).

Chadwick, O. (1964). The Reformation. London: Penguin Books.

Cowen, R. (2009). Then and Now: Unit Ideas and Comparative Education. In International Handbook of Comparative Education. (pp. 12-12777). Dordrecht Heidelberg London New York: Springer. 
Grane, L. (1990): Teaching the People - the Education of the Clergy and the Instruction of the People in the Danish Reformation Church. In Leif Grane \& Kai Hørby (eds.), Die dänische Reformation vor ihrem internationalen Hintergrund. The Danish Reformation against its International Background, (pp. 165-184). Göttingen: Vandenhoeck \& Ruprecht.

Grane, L. (2017). Den Augsburgske Bekendelse" in Den Store Danske (The Danish Encyclopedia). København/Copenhagen: Gyldendal. Taken May 10, 2017 from http://denstoredanske.dk/index.php?sideId=41932

Grue-Soerensen, K. (1956). Opdragelsens Historie (The History of Education). Copenhagen: Gyldendal.

Danmarks historie (History of Denmark) (1977). Copenhagen: Politikens Forlag, vol. 6.

Hørby, K. (1990). Humanist Profiles in the Danish Reform Movement. In L. Granef \& Kai Hørby (eds.) Die dänische Reformation vor ihrem internationalen Hintergrund. The Danish Reformation against its International Background, pp 28-39. Göttingen: Vandenhoeck \& Ruprecht.

Koch, H. (1969). Kirkens historie (History of the Church). København/Copenhagen: G. E. C. Gads Forlag.

Laustsen, M. S. (2011). Reformation i Danmark (Reformation in Denmark). København/ Copenhagen: Anis.

Laustsen, M. S. (1990).Weltliche Obrigkeit und Kirche bei König Christian III von Dänemark. In L. Grane \& Kai Hørby (eds.), Die dänische Reformation vor ihrem internationalen Hintergrund. The Danish Reformation against its international Background, (pp.91-111). Göttingen: Vandenhoeck \& Ruprecht.

Luther, M. (1524). To Councilmen of all Cities in Germany that they Establish and Maintain Christian Schools http: //www.godrules.net/library/luther/ NEW1luther_d9.htm

Luther, M. (1530). A Sermon on keeping Children in School. http://www.angelfire.com/ ny4/djw/lutherantheology.lutherchildreninschool.html

Tomlin, G. (2004). Luther og hans verden (Luther and his World). Fredericia: Lohses Forlag. 